\title{
Endothelium-role in regulation of coagulation and inflammation
}

\author{
Victor W. M. van Hinsbergh
}

Received: 2 May 2011 /Accepted: 20 July 2011 /Published online: 4 August 2011

(C) The Author(s) 2011. This article is published with open access at Springerlink.com

\begin{abstract}
By its strategic position at the interface between blood and tissues, endothelial cells control blood fluidity and continued tissue perfusion while simultaneously they direct inflammatory cells to areas in need of defense or repair. The endothelial response depends on specific tissue needs and adapts to local stresses. Endothelial cells counteract coagulation by providing tissue factor and thrombin inhibitors and receptors for protein $\mathrm{C}$ activation. The receptor PAR-1 is differentially activated by thrombin and the activated protein C/EPCR complex, resulting in antithrombotic and antiinflammatory effects. Thrombin and vasoactive agents release von Willebrand factor as ultra-large platelet-binding multimers, which are cleaved by ADAMTS13. Platelets can also facilitate leukocyte-endothelium interaction. Platelet activation is prevented by nitric oxide, prostacyclin, and exonucleotidases. Thrombin-cleaved ADAMTS18 induces disintegration of platelet aggregates while tissue-type plasminogen activator initiates fibrinolysis. Fibrin and products of platelets and inflammatory cells modulate the angiogenic response of endothelial cells and contribute to tissue repair.
\end{abstract}

Keywords Endothelial cell $\cdot$ Antithrombotic $\cdot$ Activated protein $\mathrm{C} \cdot$ von Willebrand factor. ADAMTS13.

Fibrinolysis $\cdot$ Inflammation

This article is published as part of the Special Issue on Coagulation \& Inflammation [34:1]

V. W. M. van Hinsbergh $(\bowtie)$

Laboratory for Physiology, Institute for Cardiovascular Research,

VU University Medical Center,

Van der Boechorststraat 7,

1081 Amsterdam, The Netherlands

e-mail: v.vanhinsbergh@vumc.nl

\section{Introduction}

The maintenance of blood fluidity is controlled by the inner lining of the circulatory system, a thin layer of cells, the endothelium. Endothelial cells cover the entire vasculature of vertebrates, and thus, form a hemocapatible blood container with a large surface, which has been estimated to amount $3,000-6,000 \mathrm{~m}^{2}$ [1]. Although on many places not more than $0.2 \mu \mathrm{m}$ thick, endothelial cells form a diffuse tissue of about $720 \mathrm{~g}$ in an adult person. Most of these cells are microvascular endothelial cells, and over $600 \mathrm{~g}$ of them cover the surface of capillaries [2]. In the capillaries, exchange of nutrients and hormones occurs facilitated by the exposure of a large endothelial surface area to a relatively small volume of blood. In contrast, in arteries and veins the ratio between surface and blood volume is 100 - to 500 -fold less. Furthermore, the shear forces evoked by the flowing blood vary in different types of blood vessels. Consequently, considerable variation exists in the regulation of general and specific functions between arteries, veins, arterioles, postcapillary venules, and capillaries. In addition, specific tissue demands also underlie a large variation between microvascular endothelial cells from various tissues [3].

This review focuses on the role of the endothelium in the regulation of hemostasis and thrombosis, and how an activated status of the endothelium, in particular induced by inflammation, can cause proper and improper adaptations of the endothelial phenotype.

\section{General functions of the endothelium}

In relation to their role as a gatekeeper between blood and tissues, endothelial cells are equipped with several general main functions while in addition many specific functions 
are attributed to their specific location and tissue. Living endothelial cells are required to prevent thrombus formation. Specific functions and adaptations of endothelial cells aim at maintaining blood fluidity and preventing thrombus formation. This is only possible because the endothelium also actively controls the extravasation of fluid, solutes, hormones, and macromolecules [4], as well as that of platelets and blood cells. This guarantees the availability of appropriate amounts of clotting factors and platelets. Furthermore, the endothelium, together with the smooth muscle cells, plays an important role in the control of perfusion of specific tissues and the blood tension by local vasoregulation. This is further facilitated by the responsiveness of endothelial cells to vasoactive agents, and - in particular in the lung-by involvement of the endothelium in the conversion and catabolism of vasoactive agents. Another general feature of endothelial cells is that they can become activated by inflammatory cytokines, triggers of the innate and acquired immune response, and by other stresses such as hypoxia and metabolic stress [5-8]. Such activations induce the transcription of new genes, which enable endothelial cells to offer a new repertoire of activities and receptors. Endothelial cells control the recruitment of leukocytes in areas, where these inflammatory cells are needed, in particular by expressing specific proteins cell adhesion molecules. They adapt their metabolism according to oxygen tension and metabolic needs. In inflammation, various functions of the endothelium are pivotal and well recognized from features such as tissue swelling due to a reduced barrier function, vasodilation, which also causes the red color, increased leukocyte infiltration, and alterations in the control of coagulation and thrombus formation into a more procoagulant direction. Furthermore, endothelial cells are involved in the healing process after wounding or inflammation by being the vector of angiogenesis, the formation of new blood vessels, which is essential for proper formation of granulation tissue and tissue repair as well as for re-canalization of mural and obstructing fibrin clots.

\section{Vessel- and tissue-specific functions of endothelial cells}

Related to differences in shear forces by the flowing blood, blood oxygenation, and smooth muscle content, arteries and veins display marked differences in their response to vasoactive agents and inflammatory cytokines. While the regulation of vasodilation is fast in arteries, it is considerably slower in veins. Arterial shear forces induce the transcription factor KLF2 and suppress inflammatory activation, a property that is lost in atherosclerosis-prone areas with disturbed blood flow [9-11]. The different shear forces also bear impact on the nature of thrombi, which are platelet-rich (white) in the arterial tree, while more fibrinous and red in veins. Veins also contain valves, in particular in the lower limbs, which often become initiation sites for a venous thrombus, because of disturbed flow, local hypoxia, or other unknown reasons. The high availability of the fibrinolysis regulator tissue-type plasminogen activator (t-PA) may contribute the fact that these thrombi make little contact to the endothelium while extending and growing in the bloodstream, by which they become prone to form large emboli.

A comparison of endothelial cells cultured from arteries, veins, and microvessels from various tissues demonstrated that not only arteries and veins displayed distinct differences but in particular, microvascular endothelial cells had specific genomic properties with additional differences at the tissue level [12]. This is reflected in different expression of surface receptors, such as the microvascular-specific expression of $\alpha 1 \beta 1$-integrins [13] and plasmalemma vesicle-associated protein-1, a leukocyte trafficking molecule recognized by the antibody Pal-E [14]. Tissue-specific endothelial expression of $\gamma$-glutamyl-transpeptidase and monoamine oxidase was observed in brain microvessels. Bone marrow endothelial cells express E-selectin constitutively, while in other types of endothelium E-selectin synthesis requires inflammatory activation. The lymphocyte receptor MadCam is found in endothelium of lymph nodes and Peyer's patches vessels of the intestine [15]. Fenestrae and heparin receptors are found in liver sinusoids. Thrombomodulin, while abundantly present in other endothelial cells, is poorly expressed or absent in brain microvascular and liver sinusoidal endothelial cells [16]. Differences between microvascular endothelial cells in heart, kidney, and lungs were recently reviewed by Aird [17]. In addition, the response to inflammatory cytokines and vasoactive agents differs between various vascular beds, among which the postcapillary venules often respond most pronounced. Similarly, the microvascular endothelium of different tissues responds differently in this respect, thus explaining tissue-specific pathological responses, such in Shiga toxin induced hemolytic uremic syndrome, where the Shiga toxin receptor $\mathrm{Gb} 3$ is increased by tumor necrosis factor alpha (TNF- $\alpha)$ specifically in kidney glomerular endothelial cells making them prone to damage [18].

\section{Cellular mechanisms of endothelial regulation and adaptation}

Endothelial cells respond and adapt their phenotype at various time intervals according to the nature of the stimulus $[5,19]$. These responses comprise acute release of endothelial products; immediate response to hypoxia by activation of hypoxia-inducible factors HIF-1 and HIF-2 and subsequent induction of new genes; induction of new endothelial receptors and secreted proteins by inflammatory cytokines, endotoxin, activation of toll-like receptors, and CD40 ligand; 
shedding of surface receptors following these reactions; and participation in immunological reactions.

The endothelial cells are able to respond within minutes to vasoactive agents, thrombin, or TNF- $\alpha$. This acute response follows receptor-mediated cell signaling accompanied by influx of calcium ions and induction of various types of phosphorylations, which result on the one hand in activation of enzymes that generate NO, prostacyclin/prostaglandin E2 and, in certain conditions endothelin- 1 , and on the other hand in the recruitment of vesicles with pre-formed proteins to the plasma membrane. The Weibel-Palade bodies are specific representatives of these storage organelles and release von Willebrand factor (VWF), P-selectin, and angiopoietin-2, which are involved in platelet binding, leukocyte recruitment, and inflammation modulation, respectively. But also the content of other vesicles containing the fibrinolysis regulator t-PA or the vasoconstrictor endothelin-1 can become released simultaneously depending on the vessel type. Acute release of endothelial products by thrombin is largely mediated via the protease-activated receptor-1 (PAR-1). It should be noted that earlier exposure to low thrombin concentrations causes activation of protein $\mathrm{C}$, which modifies the response of PAR-1 (see below). Furthermore, activation by vasoactive agents cause a several minutes during transient impairment of endothelial barrier function in postcapillary venules.

When endothelial cells become hypoxic, they respond immediately by rescue of hypoxia-inducible factors HIF- $1 \alpha$ and HIF- $2 \alpha$ (Fig. 1, lower part). These factors are continuously synthesized and degraded in the proteasomes after modification by prolyl and asparagyl hydroxylations and interaction with von Hippel-Lindau protein $[6,20]$. Because the HIF prolyl hydoxylases require oxygen for their activity, the absence of sufficient oxygen results in the rescue and nuclear translocation of the HIF- $\alpha$-subunits. Subsequent dimerization with HIF-1 $\beta /$ ARNT results in either HIF-1 or HIF-2 that act via specific responsive elements as transcription factors for many, probably 600 1,800 genes. They comprise genes involved in metabolism, cell survival, angiogenesis, matrix deposition, and recruitment of leukocytes and progenitor cells, such as SDF-1 and CXCR4 [6]. While HIF- $1 \alpha$ is ubiquitously present in cells, the synthesis of HIF- $2 \alpha$ is restricted to a limited number of cell

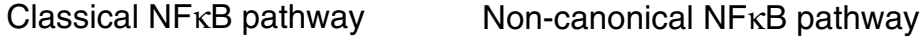

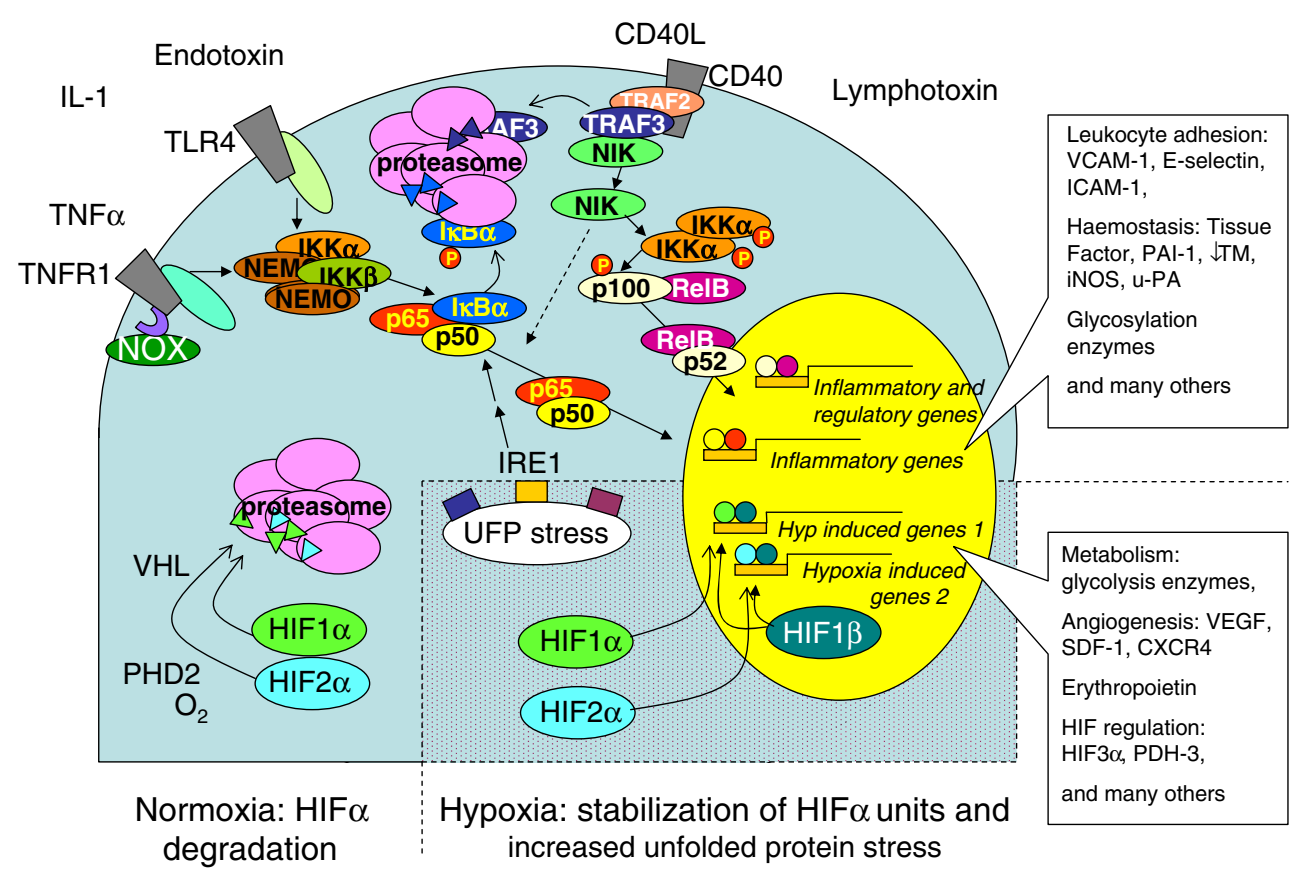

Fig. 1 Adaptation of endothelial cells to inflammatory stimuli and hypoxia. Upper part, the classical (canonical) NFKB pathway is activated by various mediators and their receptors and involves liberation of the NFKB (p65/p50) after phosphorylation and degradation of $\operatorname{I\kappa } B \alpha,-\beta$, and $-\varepsilon$ (indicated as $\operatorname{I} K B \alpha$ ). In addition, lymphotoxin and CD40 ligand can further influence endothelial activation probably via the non-canonical NFKB pathway or part of it. Further details are given in the text. Lower part, left, the two prolines of the $\alpha$-subunits of HIF-1 and HIF-2 are hydroxylated by proline hydoxylase-2 (PHD-2), which requires oxygen $\left(\mathrm{O}_{2}\right)$, after which they bind do von Hippel-Lindau
$(V H L)$ protein and are degraded in the proteasome. The lack of oxygen (lower part, right) causes rescue of the $\alpha$-subunits of HIF-1 and HIF-2, which - after nuclear entry - each dimerize with HIF $1 \beta$ and activate numerous genes. The endothelial response varies with that of many other cells as both HIF1 and HIF2 become active, while most tissue cells express only HIF1 subunits. Hypoxia can also induce unfolded protein stress, which via activation of IRE1 and subsequent steps can activate IKK and subsequently NFkB. Abbreviations: NOX NADPH oxidase; other abbreviations are given in the text 
types and prominent in endothelial cells. Besides HIF activation, the cellular protein synthesis machinery is switched to a more energy-saving program, which also can include the use of intra-ribosomal entry sites for translation of shorter proteins. Whether hypoxia also affects the regulation of hemostasis is not sufficiently known; neither how hypoxia and inflammation cooperate in the endothelial regulation of hemostasis. While hypoxia can be accompanied by inflammatory activation, it remains to be established whether this is due to a direct effect in endothelial cells, or whether activation of hypoxic monocytes results in a subsequent inflammatory response. Alternative mechanisms including unfolded protein stress may also be involved [21].

Many studies and reviews have reported on the activation of endothelial cells by endotoxin and inflammatory cytokines TNF- $\alpha$ and IL-1. These mediators activate endothelial cells via receptors that activate the classical NFKB pathway (Fig. 1, upper part). This pathway involves a complex consisting of NEMO (NFKB essential modulator) with the heterodimer I $\mathrm{BB}$ kinase- $\alpha / \beta \quad(\operatorname{IKK} \alpha / \operatorname{IKK} \beta)$, which causes phophorylationinduced detachment and proteasomal degradation of the inhibitor IKB $\alpha,-\beta$ and $-\varepsilon$ [22]. Displacement of IKB liberates the p65/p50 complex called NFKB for translocation to the nucleus. Other combinations of p65 (Rel A) and C-rel on the one hand with $\mathrm{p} 50$ and $\mathrm{p} 52$, which are derived from $\mathrm{p} 105$ and p100 NFkB precursor proteins, can also form NFkB. A similar NFKB activation occurs by toll-like receptors, in particular TLR-2 and TLR-4 in endothelial cells, which are domain recognition receptors of the innate immune system. Their primary role is to recognize common domains in bacteria and viruses, but they also recognize denatured and oxidized proteins. The presence of TLR4 was shown on various endothelial cell types and becomes significantly increased under inflammatory conditions [23]. TLR2 is also markedly enhanced by inflammation and, e.g. is present on endothelial cells of atherosclerotic lesions [24]. Other mediators, such as CD40 ligand and lymphotoxin may activate the classical NFKB pathway, but stimulate in particular a noncanonical NFkB pathway. After receptor activation this pathway includes degradation of the protein TRAF3 and subsequent NIK- (NFKB inducing kinase)-mediated dimerization of IKK, NFKB precursor protein p100 degradation with release of $\mathrm{p} 52$, which complexes with RelB and activates in the nucleus specific NFKB transcription activation sites [25].

The classical NFKB induces a range of new genes required for the inflammatory response, such as leukocyte adhesion molecules E-selectin, VCAM-1 and ICAM-1, cyclooxygenase-2, and in endothelial cells in vitro tissue factor, plasminogen activator inhibitor-1, and urokinase-type plasminogen activator. The availability of $\mathrm{NO}$ can counteract this inflammatory activation in part [26]. As arterial laminar flow enhances eNOS synthesis and activity, part of its antiatherogenic effect regards limiting inflammatory activation of the endothelium $[10,27]$. The non-canonical NFkB pathway can enforce the inflammatory activation by the classical NFKB pathway or can modulate it. Finally it should be mentioned that activation of the TNF-receptor- 1 by TNF- $\alpha$ not only activates NFKB signaling but is also linked via riboflavin kinase to the activation of NADPH oxidase [28], which may cause immediate generation of superoxide and cell activation.

Activation or release of surface-bound proteases, such as the so-called ADAMTS metalloproteinases, can cause shedding of proteins from the endothelial surface. Shedding of EPCR and thrombomodulin reduce their availability for protein $C$ activation [29, 30]. Microparticles with clusters of endothelial receptors can also be shed from the endothelial cell [31]. The glycocalyx that contains binding sites for antithrombin III and other important proteins is markedly reduced on the microvascular endothelium of diabetes patients [32] and can be proteolytically affected by heparanase from platelets [33]. The shedded proteins can sometimes harbor new functions. For example, while endothelial cells lack the IL-6 receptor, soluble IL-6 receptor shedded from other cells in severe sepsis can bind to gp130 on endothelial cells and thus induces IL-6 mediated signaling into endothelial cells, which affects leukocyte extravasation [34]. Shedded soluble thrombomodulin was shown to protect ischemic kidneys [35].

Finally, endothelial cells can participate in immune reactions and acquire high venule endothelial phenotype e.g. in rheumatoid synovium or in vitro after exposure to interferon- $\gamma[5,36]$.

\section{In vivo verification}

Studies on endothelial cells in vitro can be helpful to challenge specific questions regarding factors or mechanisms that are anticipated on the basis of observations in vivo. The findings must be verified and challenged by the in vivo complexity. In addition to information that became available from careful analysis of the background of patients with genetic defects suffering from thrombotic or bleeding disease, many studies regarding the functioning of endothelial cells in hemostasis have originated from the concept that endothelial injury/ dysfunction is an early event in the development of the atherosclerotic plaque and accompanying studies on the prevention and removal of arterial thrombi. Factors that precipitate atherosclerosis may indeed interfere with the endothelial defense system that actively counteracts the development of thrombi.

However, as pointed out elegantly by Aird [37], the vascular bed has different properties and hemostasis requirements at various sites and in different tissues. Therefore, it is important to obtain information at specific sites, such as in 
blood brain barrier microvessels which do not express thrombomodulin, in vascular pockets along vein valves that may experience stasis and hypoxia, and around glomerular endothelial cells with their specific fluid dynamics and interaction with podocytes. The recent availability of mice models in which the consequences of vascular damage can be studied in real-time in vivo by dual photon microscopy [38], in combination with transgenic models overexpressing or deficient of specific factors, provides a powerful tool that adds to the existing knowledge obtained from patients with genetic defects in coagulation or platelet factors and specific conditions which are prone to thrombosis.

\section{Endothelial control of hemostasis}

Table 1 summarizes the main features of hemostasis control by the endothelium. Endothelial cells act by promoting anticoagulant properties and counteracting platelet activation and aggregation. However, if activated by vasoactive agents, they release VWF that promotes binding of platelets and t-PA that enhances control by fibrinolysis. Furthermore, vasoconstriction is an important initial response when the vessel is damaged. It is caused by direct access of smooth muscle cells to locally generated vasoactive agents and by bypassing the vasodilatory action of endothelial cells. Impairment of these antithrombotic properties of the endothelium either by genetic or acquired deficiencies or by alteration of endothelial gene expression in severe inflammation can cause severe thrombotic complications. The next section shall discuss these aspects in more detail.

\section{Tissue factor and tissue factor pathway inhibitor}

In vivo coagulation requires the availability of the transmembrane protein tissue factor, the initiator of the extrinsic coagulation pathway. Tissue factor dependent signaling is required for embryo development but dispensible for hemostasis[39]. Its extracellular domain binds and enhances the proteolytic activity of factor VII, which in turn activates factor X and factor IX by enzymatic cleavage. Activated factor $\mathrm{X}(\mathrm{Xa})$ subsequently activates prothrombin to thrombin, the protease that converts fibrinogen into fibrin. The additional activation of factor IX by factor VIIa is important, because factor Xa together with factor VIIa are bound to inhibitory Kunitz domains of the protein tissue factor pathway inhibitor (TFPI) and become rapidly inhibited together. TFPI is expressed particularly in microvascular endothelium where it is bound to its surface [40]. However, it also acts on the
Table 1 Hemostasis control by endothelial cells

\footnotetext{
Abbreviations: $V W F$ von

Willebrand factor, $U L V W F$

ultra-large VWF, ADAMTS13 a

disintegrin and

metalloproteinase with a

thrombospondin type 1 motif,

member 13, $N O$ nitric oxide,

$P G I 2$ prostacyclin, $P G E 2$

prostaglandin $\mathrm{E} 2, t-P A$

tissue-type plasminogen activator, $P A I-1$ plasminogen activator inhibitor-1, $u-P A$ urokinase-type plasminogen activator, UPAR u-PA receptor, MT1-MMP membrane-type matrix metalloproteinase-1 C-terminal carboxy-terminal
}

\author{
Control of coagulation \\ Binding of antithrombin III \\ Thrombomodulin (TM) expression and protein $\mathrm{C}$ activation \\ Expression of endothelial protein $\mathrm{C}$ receptor (EPCR) \\ Release of tissue factor pathway inhibitor (TFPI) \\ Incidentally: tissue factor induction (in some tumors) \\ Control of platelet adhesion and activation \\ Production and acute release of VWF \\ Cleavage of ULVWF by ADAMTS13 \\ Electrical repulsion by negatively charged heparan sulfates \\ Reduction of platelet activation by release of NO and PGI2/PGE2 \\ Surface expression of ectonucleotidases
}

Fibrinolysis

Synthesis and acute release of t-PA

Induction of PAI-1 (in specific activated conditions)

u-PA/UPAR and MT1-MMP (mainly cell invasion)

Platelet disintegration

Thrombin-cleaved ADAMTS18 (C-terminal fragment)

Vasoregulation (in part modulated by endothelial cells)

Constriction as first defence line against acute bleeding

Dilation in an attempt to move an initial thrombus to a smaller tissue area 
arterial endothelium, as its deletion also causes increased ferric chloride-induced arterial thrombosis in mice [41]. The simultaneously activated factor IXa can activate additional factor X molecules so that the coagulation pathway can still proceed when factor VIIa is inactivated.

Tissue factor is present on tissue cells beyond the microcirculation and in the adventitia and plaques of conduit vessels. In inflammation and sepsis, it becomes strongly induced in monocytes-macrophages [42, 43]. Indeed, while vessel accompanying cells, such as fibroblasts, are the source of tissue factor in an acutely damaged vessel, monocytes are the prime source in inflammation and hypoxia. It is true that inflammatory cytokines rapidly induce tissue factor on cultured endothelial cells [44], but subsequent in vivo studies have been unable to detect its expression in vivo in similar conditions. Only in specific subsets of endothelial cells in severe sepsis and local flow disturbances in baboons and in human tumors the presence of tissue factor has been demonstrated on endothelial cells in vivo [42, 45, 46]. One study described the presence of tissue factor containing microvesicles in the basement membrane of endothelial cells of LPS-stimulated bovine aorta [47]. However, although recent studies on circulating microparticles indicate the presence of tissue factor in platelet microparticles, its presence on in vivo circulating endothelial microparticles, in contrast to in vitro generated ones, is still uncertain [31, 48, 49]. As pointed out by Mackman [39], the presence of tissue factor on activated endothelium in vivo may be alternatively explained as being attributable to the deposition of monocyte-derived tissue factor-positive microparticles, similar as demonstrated for granulocytes [50]. Recent studies on NY1DD sickle mouse, which exhibits a low-TF to highTF phenotype switch on exposure to hypoxia/reoxygenation, suggested that the lack of NO availability can induce TF in endothelial cells in vivo [51].

It should be noted that tissue factor in the cell membrane or microparticles is often present in an inactive form containing unpaired cysteine thiols and requires conversion of Cys186 and Cys 209 into a disulfide bond by protein disulfide isomerase to become active. In vivo data indicated that after laser-induced vessel wall injury protein disulfide isomerase from endothelial cells rather than from platelets contributed to the enhanced thrombus generation [52]. Thus, the endothelial control on the initiation of coagulation is twofold. In healthy endothelium, TFPI limits TF/VIIa/Xa activity [41]. Furthermore, while the synthesis of tissue factor by inflammationactivated endothelial cells in vivo remains uncertain, endothelial protein disulfide isomerase can enhance the activity of cryptic tissue factor in circulating microparticles. Additional roles for this enzyme in the arrangement of other disulfide interactions are not yet known but cannot be excluded

\section{Anti-coagulant properties of the endothelium after thrombin generation}

Similarly as factor VIIa needs the membrane-anchored tissue factor, the activation of prothombin by factors Xa and $\mathrm{X}$ activation by factor IXa require the cofactors Va and VIIIa, respectively (both activated by thrombin), and the availability of a negatively charged phospholipids surface. The latter is provided by platelets once they become activated by thrombin or by contact with the damaged vessel wall or tissue. Therefore, once the coagulation has started to produce thrombin, it becomes highly amplified. It is therefore important that the endothelial surface provides several proteins and receptors that inhibit thrombin and counteract the progress of coagulation.

The potent thrombin inhibitor antithrombin III binds to specific heparan sulfates of proteoglycans in the glycocalyx that covers the endothelial surface [53]. Inadequate antithrombin III activity is accompanied by severe thrombotic complications. Furthermore, a triad of endothelial receptors is involved in the generation the important anti-coagulant activated protein $\mathrm{C}(\mathrm{aPC})$, which can interrupt the coagulation cascade by cleavage of factors Va and VIIIa, and in mediating its cellular anti-inflammatory action. They comprise thrombomodulin, the endothelial protein $\mathrm{C}$ receptor (EPCR) and PAR-1, which displays an altered signaling when activated by the EPCR/aPC complex instead of thrombin.

\section{Thrombomodulin, EPCR, and PAR-1: strong together}

Thrombomodulin is synthesized predominantly-but not exclusively-by endothelial cells. It is ubiquitously expressed, except for the microvasculature of the brain where it is undetectable [54]. Thrombomodulin transcription is enhanced in endothelial cells by arterial shear forces, which involves the transcription factor KLF-2 [11]. It is reduced by inflammatory mediators, and can be rapidly decreased by proteolytic shedding. As a membrane protein is present at the surface of the endothelial lining, where it catalyzes the conversion of protein $\mathrm{C}$ into aPC by thrombin. This is facilitated by EPCR, which is abundantly present on endothelial cells. EPCR binds protein $\mathrm{C}$ with high affinity to the surface of endothelial cells adjacent to the thrombomodulin-thrombin complex, so that a relatively high local protein $\mathrm{C}$ concentration and effective aPC generation is achieved. aPC will split and inactivate the cofactors Va and VIIIa, in part in interaction with protein $\mathrm{S}$, and thereby shut down continued coagulation. The importance of this pathway is underscored by the occurrence of thrombosis in patients, who display (partial) deficiencies in protein $\mathrm{C}$ or thrombomodulin and in carriers of a factor $\mathrm{V}$ variant that is poorly degraded by aPC, factor $\mathrm{V}_{\text {Leiden }}$. Mutations in thrombomo- 
dulin can also underlie the occurrence of hemolytic uremic syndrome in specific patients [55]. Thrombomodulin is also involved in the activation of tissue-associated fibrinolysis inhibitor [56], which inactivates complement factor C5a [57].

EPCR does not only bind protein $\mathrm{C}$ via its Gla-domain of protein $\mathrm{C}$ but also aPC with equally high affinity [58]. At appropriate sites of the plasma membrane, namely in the lipid rafts, the EPCR-aPC couples to PAR-1 [59]. At these sites, the complex also interacts specifically with caveolin at the inner side of the plasma membrane [60]. In cultured endothelial cells $25-30 \%$ of PAR- 1 is available for such interaction, the reminder remaining available for thrombin [61]. However, aPC in the aPC/EPCR complex activates PAR-1 in a different way than thrombin possibly also involving differences in the interaction with caveolin. Instead of an activation of PAR-1 via G12/13 proteins, it activates much stronger a Gi protein, by which anti-inflammatory properties are activated in the endothelial cell, and probably also in hemopoietic cells.

In the context of its anti-inflammatory properties, a number of studies focused on an improvement of the endothelial barrier function by aPC. In in vitro studies, activation of endothelial PAR-1 by interaction with the EPCR-aPC complex caused activation of Gi protein and MAPK phosphorylation with subsequent sphingosine-1-phosphate (S-1-P) generation and cross-activation of the S-1-P receptor-1 [6265]. This latter activation leads to activation of Rac-1 [66], which has endothelial barrier improving properties [4]. Endogenous activated protein $\mathrm{C}$ may also limit cancer cell extravasation by a similar mechanism [67]. Because infusion of aPC or S-1-P $2 \mathrm{~h}$ prior to endotoxin challenge reduced mortality in mice, this mechanism was considered to be active in endotoxinemic mice [61]. However, while S-1-P is known as a barrier stabilizer, also in the absence of aPC [68], the data on aPC pre-infusion might also be interpreted differently. Several recent studies indicate that hemopoietic cells play a role in reducing mortality of endotoxinemia in animals rather than direct barrier protective properties by aPC/EPCR/PAR-1-mediated signaling in endothelial cells $[69,70]$. Amelioration of colitis by aPC in mice involved a reduction of leukocyte adhesion [71], so that the effect may be even at both the hemopoietic and endothelial cell level.

Endothelial NFKB activity plays a crucial role in multiple organ failure and tissue damage in sepsis [72]. As activation of the endothelial NFKB pathway reduces thrombomodulin and EPCR expression and increases their shedding from the endothelial surface, probably by AMADTS-17 activity, such activation impairs the protein $\mathrm{C}$ anti-coagulant mechanism in endotoxinemia [73]. However, activated protein $\mathrm{C}$ protects endothelial cells and limits its inflammatory activation by activation of both the non-canonical NFKB pathway and ERK1,2 activation [74, 75].

The anti-inflammatory activation of PAR-1 by aPC adds to the well known PAR-1 activation by thrombin, which in endothelial cells induces a number of cellular responses that counteract the thrombotic response that is initiated by thrombin (Fig. 2). Thrombin activation of PAR-1 induces several routes of intracellular signaling, by which (a) nitric oxide (NO) and prostacyclin production are enhanced, which cause vasodilation and limit platelet activation; (b) $\mathrm{t}$-PA is released that binds to the fibrin generated and causes effective fibrinolysis; and (c) Weibel-Palade bodies are activated that release VWF, angiopoietin-2, and P-selectin, the latter two also enhancing a subsequent inflammatory response by PMNs. All these reaction occur within minutes. The precise extent of the various aspects of this response, also called acute response, can vary between different types
Fig. 2 Effects of thrombin on endothelial cell regulation of hemostasis. Abbreviations: TM thrombomodulin, $A P C$ activated protein C, ATIII antithrombin III, $P A R-1$ protease-activated receptor-1, EPCR endothelial protein $\mathrm{C}$ receptor, $t-P A$ tissue-type plasminogen activator, $W P B$ Weibel-Palade body, $V W F$ von Willebrand factor, $U L V W F$ ultra-large VWF, ADAMTS18 a disintegrin and metalloproteinase with a thrombospondin type 1 motif, member 18, C-terminal carboxy-terminal, $N O$ nitric oxide, eNOS endothelial NO synthase, $P G I 2$ prostacyclin, $P G E 2$ prostaglandin E2

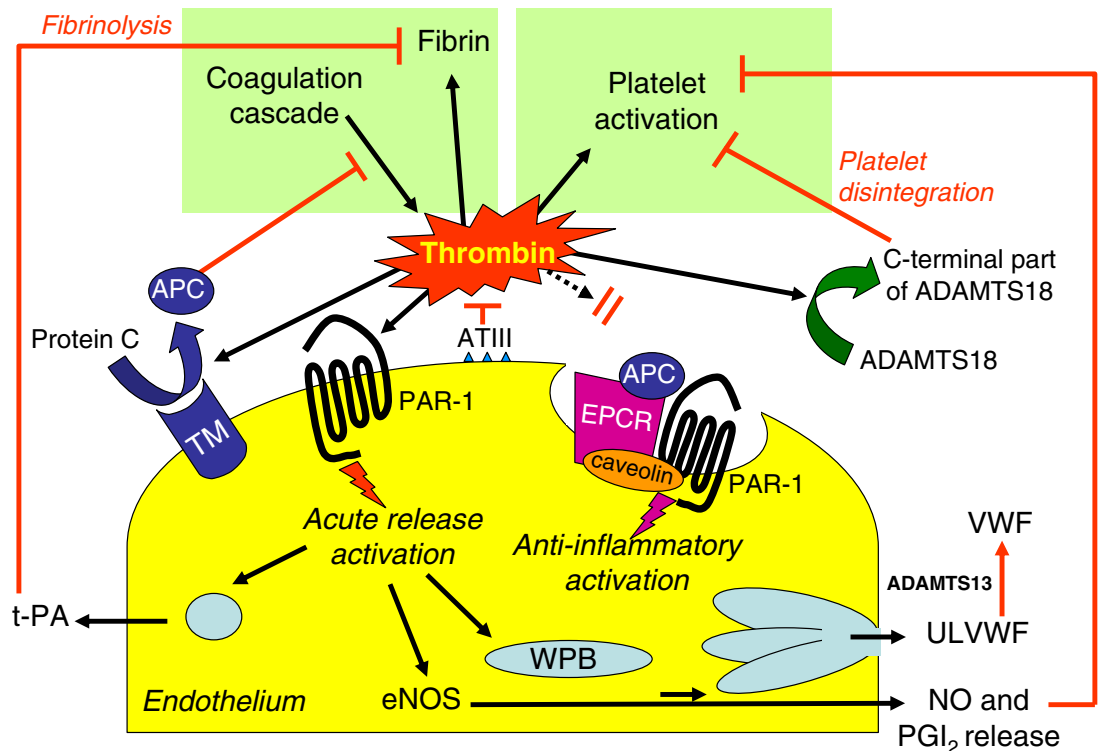


of blood vessels and between tissues, as indicated above for NO, prostacyclin, and t-PA. The number of Weibel-Palade bodies also can vary between different types of vessels.

\section{VWF release and control of its ultra-large multimers}

VWF is the major protein of the Weibel-Palade body and its multimers cause a striped structure when visualized in the electron microscope [76]. VWF is only synthesized in endothelium and megakaryocytes and present in $\alpha$-granules of platelets. After synthesis in the endothelial endoplasmic reticulum, VWF is processed in the Golgi complex. By the lower $\mathrm{pH}$ in the terminal Golgi complex, VWF molecules form back to back dimers, which subsequently become spontaneously packed as multimers in a spiral-like fashion [77]. In this way, the specific Weibel-Palade body is formed, which remains the storage organelle for VWF until its release into the blood. Basal secretion of VWF proceeds via the same route [78]. Besides VWF, P-selectin and angiopoietin-2 are deposited in and released from the Weibel-Palade bodies [79, 80]. Furthermore, several other proteins can be encountered in the Weibel-Palade bodies, such as t-PA and IL-8, but only a small fraction of these proteins is stored in this specific organelle.

VWF can be released from the endothelial cells by vasoactive agents, such as histamine, bradykinin, and vasopressin, and thrombin, which enhance cytoplasmic calcium concentration and activate protein kinase C. During this release process, that occurs within 5-10 min single and clusters of Weibel-Palade bodies fuse with the plasma membrane and release VWF [81, 82]. If the endothelial cells are stimulated by cAMP-elevating agents, only a part of the Weibel-Palade bodies is released that contain VWF, but little P-selectin [83]. Probably by the exposure to the neutral $\mathrm{pH}$ of the blood, VWF is unfolding and so-called ultra-large VWF multimers (ULVWF) are formed on the surface of the endothelium, which can amount up to several $\mathrm{mm}$ in length, when formed by combination of the VWF content of several Weibel-Palade bodies. These ULVWF multimers align along the surface of the endothelium or damaged vessel, and are able to bind platelets directly by interaction of their VWF-A1 domains with platelet $\mathrm{GpIb} \alpha$ moieties. Under high shear forces, platelet GpIIb can bind to VWF-A3 domains.

On the surface of the endothelium, these ULVWF multimers are cut in smaller multimers by the action of the metalloproteinase ADAMTS13, which stands for a disintegrin-like and metalloprotease with thrombospondin type 1 repeats-13 [84]. ADAMTS-13 binds to the VWF-A3 domain and cuts individual VWF molecules at a specific site $\left(\operatorname{Tyr}_{1605}-\mathrm{Met}_{1606}\right)$ within the VWF-A2 domain. This proteolytic activity, which is facilitated by ADAMTS13 binding to the endothelial surface, results within minutes in the generation of shorter VWF multimers and a conversion of the extended strings of ULVWF into smaller more globular VWF multimers of less than $20 \mu \mathrm{m}$. Hence, VWF multimers with variable length become circulating in plasma but once detached into the circulation the binding and cleavage sites for ADAMTS13 on the A2-A3 domains of VWF multimers or platelet-VWF complexes is buried in its round-up structure and becomes only available again under high fluid shear forces [85].

\section{ADAMTS13}

ADAMTS13 is synthesized in liver stellate cells, endothelial cells, and present in platelets. Furthermore, it is synthesized in kidney podocytes and deposited in the glomerular basement membrane, where it may have a specific function in preventing thrombus formation. Given the overall mass of endothelial cells in the body, one may anticipate that endothelial cells have a considerable if not major contribution to the production of ADAMTS13 in the blood. ADAMTS13 is also active when it still contains its propeptide, and performs activity when appropriately bound to VWF [86].

ADAMTS13 bound to endothelial cells exhibited enhanced cleavage of VWF. This binding involves the C-terminal thrombospondin domain ADAMTS13 and occurred independently of VWF [87]. Davis et al. [88] suggested that CD36 is a good candidate for this binding. These data may underlie the observations that trombospondin-1-by competitionprotects VWF from cleavage by ADAMTS13 [89] and may bear impact on the observation that CD36 antibodies were found in patients with hemolytic uremic syndrome [90].

In addition to deficiency of ADAMTS13 activity by mutation or generation of auto-antibodies, a partial reduction of ADAMTS-13 activity due to reduced synthesis has been reported in severe inflammatory conditions, although the extent of this reduction varies between different studies [91, 92]. A suppressive effect of inflammatory mediators is underscored by the findings that endotoxin infusion in healthy human volunteers caused a $36 \%$ decrease of ADAMTS13, in addition to an increase in VWF [93] and by a short report showing that ADAMTS13 mRNA and proteolytic activity was reduced by interferon- $\gamma, \mathrm{TNF}-\alpha$ and interleukin- 4 in rat primary hepatic stellate cells and human endothelial cells in vitro [94].

Animal studies may provide additional information. ADAMTS13 deficiency in mice results in a prothrombotic phenotype and VWF platelet strings in histamine-stimulated mesenteric veins but not in arterioles [95]. In addition, it also slows down leukocyte rolling in these vessels, and increased influx of PMNs in thioglycolate-induced peritonitis and into skin tissue in excision wounds [95]. Shiga toxin triggers TTP in a subset of ADAMTS13-deficient mice, but this response required an additional triggering event [96]. The smaller Shiga 
toxin B subunits, rather than the usually active A-subunit, induce VWF secretion and thrombotic microangiopathy in ADAMTS-deficient mice [97]. On the other hand, ADAMTS13 inhibition in baboons was sufficient to cause TTP in the absence of inciting triggers [98].

\section{Interruption of platelet activation and vasodilation}

Platelets are normally repelled from the surface of the endothelium by the negatively charged glycosaminoglycans, but this defense can be overcome in activated platelets by receptor-ligand interactions, namely the binding of P-selectin to the protein PSGL-1 that bears P-selectin sugar ligands, binding of GpIb $\alpha$ to either P-selectin or VWF on the surface of the endothelium, and indirectly via a fibrin bridge that joins GpIIb/IIIa and ICAM-1. Platelet heparanase, which is released from activated platelets, can facilitate this interaction by degrading proteoglycans in the endothelial glycocalyx.

Endothelial cells actively prevent or limit thrombus formation by suppressing platelet adhesion and activation [99]. The surface of endothelial cells harbors ectonucleotidases (CD39), which rapidly convert the platelet-stimulating ADP into adenosine [100]. Platelet activation is counteracted by prostacyclin and prostaglandin E2, which are liberated from the endothelium after stimulation by vasoactive agents and thrombin. Prostacyclin is produced by the endothelium of large vessels, while the endothelial cells from smaller vessels produce predominantly prostaglandin E2 [101]. The effect of prostacyclin is enhanced by nitric oxide, which is produced by endothelial nitric oxide synthase (eNOS). Nitric oxide production is rapidly enhanced after exposure of endothelial cells to vasoactive agents that enhance the cytosolic calcium ion concentration, and by exposure of the endothelium to arterial shear forces, which induce eNOS synthesis and enhance its activity by phosphorylation of Ser 1177 (Ser1179 in mouse) [102, 103].

The importance of NO as antithrombotic mediator was also demonstrated in a recent study on the prothrombotic effect of antiphospholipid antibodies in mice [104]. The antiphospholipid syndrome is accompanied by recurrent thrombosis. Ramesh et al. [104] showed that interaction of the complex between a dimer of $\beta_{2}$-glycoprotein- 1 and antiphospholipid antibody interacts with the LDL-binding domain of the so-called apoER2 lipoprotein receptor by which the protein phosphatase PP2A was activated and eNOS was dephosphorylated at its Ser1179 site. This reduced NO production markedly and resulted in increased leukocyte adhesion to endothelial cells and increased tendency to thrombus formation.

It should be noted that nitric oxide, prostacyclin, prostaglandin E2, and adenosine also induce vasodilatation. While vasoconstriction is a first response of a damaged vessel to limit blood loss, rapid vasodilation can help to limit the area of ischemia once an initial thrombus has been formed in the arterial leg of the circulation. By immediate vasodilatation, a new thrombus may move to a more distal part of the vascular tree, so that it will cause ischemia in a smaller area, in particular if such a thrombus passes across a branch point of the distal vessel.

\section{Disintegration of platelet aggregates}

The previous mechanisms all aim at preventing platelet activation and aggregation. Interestingly, a recent study pointed to an additional mechanism in thrombin-activated endothelial cells that is aimed at disintegrating platelet aggregates that have already been formed [105]. Thrombin not only enhances the secretion of ADAMTS18, but also uncovers by proteolytical cleavage a new activity in the obtained $45 \mathrm{kD}$ C-terminal part of ADAMTS18. The C-terminal ADAMTS18 fragment that is generated contains a newly exposed 18 mer moiety that binds to platelet GPIIIa49-66. By this interaction, platelet aggregates become destroyed by oxidative platelet fragmentation. This was not only observed in vitro, but the ADAMTS18 fragment also limited $\mathrm{FeCl}_{3}$-induced carotid artery thrombosis in mice as well as cerebral infarction in a murine postischemic stroke model in vivo [105].

\section{Fibrinolysis}

Endothelial cells also provide a mechanism that counteracts the accumulation fibrin, the product of coagulation. To that end, endothelial cells produce t-PA, the prime regulatory component for activating the fibrinolytic system in blood and body cavities [106]. Both single-chain and double-chain t-PA activate the liver-derived zymogen plasminogen into plasmin, but t-PA requires binding to fibrin before it obtains activity. The broadly acting protease plasmin subsequently degrades fibrin into fibrin degradation products. Endothelial cells produce and release continuously t-PA, which is cleared within 10-15 $\mathrm{min}$ by the liver, unless it has encountered fibrin to which it binds. In this way t-PA monitors the patency of blood vessels and removes via fibrinolysis hidden deposition of fibrin in the vessels. Furthermore, t-PA becomes acutely released from storage organelles after exposure of endothelial cells to vasoactive agents or thrombin. The high availability of t-PA at the moment that a fibrin network is forming ensures the binding of t-PA within the clot, by which it is much more effective in fibrinolysis than when t-PA is added from the outside to an existing clot.

There exists some dispute about the nature of the storage vesicles for t-PA [107, 108]. Although t-PA has been encountered in Weibel-Palade bodies, it is generally believed that this represents only a minor fraction of t-PA in the 
endothelial cells. After carefully establishing the conditions for inducing adequate acute release of t-PA in endothelial cells, Emeis et al. [107] demonstrated that t-PA was present in specific vesicles, that were separate of the VWF containing Weibel-Palade bodies and other endothelin-containing vesicles. These "Emeisosomes" are probably involved in both basal and induced release of t-PA.

In the absences of plasminogen MT1-MMP also can act as a fibrinolysin [109]. Furthermore, endothelial can synthesize a second plasminogen activator, urokinase-type (u-PA), when they are activated by inflammatory cytokines, such as TNF- $\alpha$, IL-1, endotoxin, or lymphotoxin [110]. Its activity is confined to the cell surface by the urokinase receptor (UPAR) [111]. It is generally believed that MT1-MMP and u-PA play important roles in pericellular proteolysis during cell migration, matrix invasion, and angiogenesis [112-114]. u-PA bound to UPAR is also involved in leukocyte and progenitor cell migration invasion, which may underlie the observation that selective abrogation of the u-PA/UPAR interaction plays a pivotal role in the suppression of chronic inflammation to exacerbated fibrin deposition [115].

Both the activity of t-PA and u-PA are inhibited by plasminogen activator-1 (PAI-1). PAI-1 is produced in large amounts by cytokine-stimulated cultured endothelial cells, but the contribution of endothelial PAI-1 in vivo has been debated. Platelets contain PAI-1, and liver and adipose tissue cells respond to cytokines TNF- $\alpha$ and TGF- $\beta$ by enhanced production of PAI-1 [44, 116, 117]. PAI-1 can also interact with aPC [118, 119], but the physiological meaning of this interaction is less clear. Interestingly, PAI-1 is secreted as an active molecule but rapidly loses its activity, probably by exposure to the more oxidative environment which induces a structural change. When PAI-1 interacts with u-PA, the complex is cleared by UPAR. In this way, the large availability of PAI-1 and UPAR can reduce the u-PA concentration in the environment of the cell.

\section{Haemostasis and inflammation in tissue repair and angiogenesis}

The haemostatic plug not only acts as a sealing of the tissue after wounding, but also as the scaffolding for invading cells during the subsequent healing process. Thrombin can also be considered as a growth factor and can stimulate angiogenesis and vascular remodeling. Activated protein $\mathrm{C}$ has antiapoptotic properties for endothelial cells. The transient fibrin matrix is an excellent matrix for endothelial cells to act as scaffolding for new capillary structures $[120,121]$. The presence of a fibrinous exudate can facilitate the angiogenesis process by providing factors and matrix for the invasion and expansion of new microvessels. Angiogenesis is induced by angiogenic growth factors often in combination with inflam- matory mediators or other factors induced by ischemia or secreted by platelets. Furthermore, several fibrin degradation products can activate or protect the endothelium [122-125].

In addition to their pivotal role in the formation of the hemostatic plug, platelets facilitate tissue repair and inflammation. Platelets are a rich source of factors that stimulate tissue repair and facilitate interaction between leukocytes and endothelial cells. They accumulate and release, after activation, many vasoactive agents and chemokines, such as serotonin, thromboxane A2, platelet activating factor and RANTES, and angiogenic growth factors, in particular VEGF, that is secreted in a potent fibronectin-bound form [126]. These factors are stored in $\alpha$-granules and released upon activation of the platelet [127]. Interestingly, angiogenesis inhibiting proteins, such as thrombospondin-1 and endostatin, are stored in separate granules in the same platelet [127]. Thus, platelets are potentially powerful regulators of tissue repair associated angiogenesis.

After stimulation, platelets also release P-selectin from a specific area in the $\alpha$-granules which then becomes expressed on their surface. P-selectin plays an important role in the recruitment of platelets on neutrophils and monocytes and in their interaction with endothelial cells [128, 129]. Finally, activated platelets also produce and expose CD40 ligand (CD40L or CD154), which can interact with leukocytes or activate the non-canonical NFKB pathway in endothelial cells and thus enhance the expression of leukocyte receptors and enhance the production of chemokines MCP-1 and interleukin-8 [130]. In this way, platelet play important roles in inflammation and sepsis, as well as in immunoregulation, such as occurs in the atherosclerotic plaque $[129,130]$.

\section{Conclusions}

By its strategic position at the interface between blood and tissues, the endothelium controls blood fluidity and continued tissue perfusion while at the same time it directs recruitment of inflammatory cells to areas that need defense or repair. From the foregoing discussion, it becomes clear that endothelial cells at different sites in the body achieve a delicate fine tuning, by which coagulation, thrombus formation, and inflammation are kept in balance and adapted to the local needs. Notwithstanding, these balances can become disturbed in by genetic, immunologically acquired deficiencies and by overreactions to microbes and toxins. Better understanding of the underlying mechanisms that contribute to thrombotic and inflammatory disease will be the basis for further development of effective treatments to combat these complications. At the same time, it is fascinating how delicately the interaction between hemostasis and inflammation is regulated by the endothelium. 
Acknowledgments The authors would like to thank Hans de Zeeuw and Isabelle Vergroesen for their help in preparing the manuscript. VvH was supported by the Netherlands Initiative for Regenerative Medicine.

Open Access This article is distributed under the terms of the Creative Commons Attribution Noncommercial License which permits any noncommercial use, distribution, and reproduction in any medium, provided the original author(s) and source are credited.

\section{References}

1. Gimbrone MA et al (1986) Vascular endothelium: nature's blood container. In: Vascular endothelium in hemostasis and thrombosis. Churchill Livingstone, New York, pp 1-13

2. Wolinsky H (1980) A proposal linking clearance of circulating lipoproteins to tissue metabolic-activity as a basis for understanding atherogenesis. Circ Res 47:301-311

3. Aird WC (2007) Phenotypic heterogeneity of the endothelium I. Structure, function, and mechanisms. Circ Res 100:158-173

4. Mehta D, Malik AB (2006) Signaling mechanisms regulating endothelial permeability. Physiol Rev 86:279-367

5. Pober JS, Sessa WC (2007) Evolving functions of endothelial cells in inflammation. Nat Rev Immunol 7:803-815

6. Semenza GL (2010) Vascular responses to hypoxia and ischemia. Arterioscler Thromb Vasc Biol 30:648-652

7. Bakker W, Eringa EC, Sipkema P, van Hinsbergh VWM (2009) Endothelial dysfunction and diabetes: roles of hyperglycemia, impaired insulin signaling and obesity. Cell Tissue Res 335:165-189

8. Fraisl P, Mazzone M, Schmidt T, Carmeliet P (2009) Regulation of angiogenesis by oxygen and metabolism. Dev Cell 16:167179

9. Lin Z, Kumar A, SenBanerjee S, Staniszewski K, Parmar K, Vaughan DE, Gimbrone MAJ, Balasubramanian V, GarciaCardena G, Jain MK (2005) Kruppel-like factor 2 (KLF2) regulates endothelial thrombotic function. Circ Res 96:e48-e57

10. Dekker RJ, van Thienen JV, Rohlena J, de Jager SC, Elderkamp YW, Seppen J, de Vries CJM, Biessen EAL, van Berkel TJC, Pannekoek H, Horrevoets AJG (2005) Endothelial KLF2 links local arterial shear stress levels to the expression of vascular tone-regulating genes. Am J Pathol 167:609-618

11. Parmar KM, Larman HB, Dai GH, Zhang YH, Wang ET, Moorthy SN, Kratz JR, Lin ZY, Jain MK, Gimbrone MA, Garcia-Cardena G (2006) Integration of flow-dependent endothelial phenotypes by Kruppel-like factor 2. J Clin Investig 116:49-58

12. Chi JT, Chang HY, Haraldsen G, Jahnsen FL, Troyanskaya OG, Chang DS, Wang Z, Rockson SG, Van de Rijn M, Botstein D, Brown PO (2003) Endothelial cell diversity revealed by global expression profiling. Proc Natl Acad Sci U S A 100:1062310628

13. Defilippi P, Vanhinsbergh V, Bertolotto A, Rossino P, Silengo L, Tarone G (1991) Differential distribution and modulation of expression of alpha1/beta1 integrin on human endothelial-cells. J Cell Biol 114:855-863

14. Keuschnigg J, Henttinen T, Auvinen K, Karikoski M, Salmi M, Jalkanen S (2009) The prototype endothelial marker PAL-E is a leukocyte trafficking molecule. Blood 114:478-484

15. Berlin C, Berg EL, Briskin MJ, Andrew DP, Kilshaw PJ, Holzmann B, Weissman IL, Hamann A, Butcher EC (1993) Alpha-4-Beta-7-integrin mediates lymphocyte binding to the mucosal vascular addressin Madcam-1. Cell 74:185-195

16. Laszik Z, Mitro A, Taylor FB, Ferrell G, Esmon CT (1997) Human protein $\mathrm{C}$ receptor is present primarily on endothelium of large blood vessels - Implications for the control of the protein $\mathrm{C}$ pathway. Circulation 96:3633-3640

17. Aird WC (2007) Phenotypic heterogeneity of the endothelium II. Representative vascular beds. Circ Res 100:174-190

18. vanSetten PA, vanHinsbergh VWM, vanderVelden TJAN, vandeKar NCAJ, Vermeer M, Mahan JD, Assmann KJM, vandenHeuvel LPWJ, Monnens LAH (1997) Effects of TNF alpha on verocytotoxin cytotoxicity in purified human glomerular microvascular endothelial cells. Kidney Int 51:1245-1256

19. Cines DB, Pollak ES, Buck CA, Loscalzo J, Zimmerman GA, Mcever RP, Pober JS, Wick TM, Konkle BA, Schwartz BS, Barnathan ES, Mccrae KR, Hug BA, Schmidt AM, Stern DM (1998) Endothelial cells in physiology and in the pathophysiology of vascular disorders. Blood 91:3527-3561

20. Semenza GL (2009) Regulation of oxygen homeostasis by hypoxia-inducible factor 1 . Physiology 24:97-106

21. Wouters BG, Koritzinsky M (2008) Hypoxia signalling through $\mathrm{mTOR}$ and the unfolded protein response in cancer. Nat Rev Canc 8:851-864

22. Hoffmann A, Levchenko A, Scott ML, Baltimore D (2002) The I kappa B-NF-kappa B signaling module: temporal control and selective gene activation. Science 298:1241-1245

23. Faure E, Thomas L, Xu H, Medvedev AE, Equils O, Arditi M (2001) Bacterial lipopolysaccharide and IFN-gamma induce Tolllike receptor 2 and Toll-like receptor 4 expression in human endothelial cells: role of NF-kappa B activation. J Immunol 166:2018-2024

24. Hansson GK (2009) Inflammatory mechanisms in atherosclerosis. J Thromb Haemost 7:328-331

25. Bista P, Zeng WK, Ryan S, Bailly V, Browning JL, Lukashev ME (2010) TRAF3 controls activation of the canonical and alternative NF kappa B by the lymphotoxin beta receptor. J Biol Chem 285:12971-12978

26. Qian HS, Neplioueva V, Shetty CA, Channon KM, George SE (1999) Nitric oxide synthase gene therapy rapidly reduces adhesion molecule expression and inflammatory cell infiltration in carotid arteries of cholesterol-fed rabbits. Circulation 99:2979-2982

27. Sen-Banerjee S, Mir S, Lin ZY, Hamik A, Atkins GB, Das H, Banerjee P, Kumar A, Jain MK (2005) KLF2 as a novel mediator of statin effects in endothelial cells. Circulation 112:720-726

28. Yazdanpanah B, Wiegmann K, Tchikov V, Krut O, Pongratz C, Schramm M, Kleinridders A, Wunderlich T, Kashkar H, Utermohlen O, Bruning JC, Schutze S, Kronke M (2009) Riboflavin kinase couples TNF receptor 1 to NADPH oxidase. Nature 460:1159-1163

29. Gu JM, Katsuura Y, Ferrell GL, Grammas P, Esmon CT (2000) Endotoxin and thrombin elevate rodent endothelial cell protein $\mathrm{C}$ receptor mRNA levels and increase receptor shedding in vivo. Blood 95:1687-1693

30. Wu HL, Lin CI, Huang YL, Chen PS, Kuo CH, Chen MS, Wu GCC, Shi GY, Yang HY, Lee H (2008) Lysophosphatidic acid stimulates thrombomodulin lectin-like domain shedding in human endothelial cells. Biochem Biophys Res Commun 367:162-168

31. Dignat-George F, Boulanger CM (2011) The many faces of endothelial microparticles. Arterioscler Thromb Vasc Biol 31:27-33

32. Nieuwdorp M, van Haeften TW, Gouverneur MCLG, Mooij HL, van Lieshout MHP, Levi M, Meijers JCM, Holleman F, Hoekstra JBL, Vink H, Kastelein JJP, Stroes ESG (2006) Loss of endothelial glycocalyx during acute hyperglycemia coincides with endothelial dysfunction and coagulation activation in vivo. Diabetes 55:480-486

33. Vlodavsky I, Eldor A, Haimovitzfriedman A, Matzner Y, Ishaimichaeli R, Lider O, Naparstek Y, Cohen IR, Fuks Z 
(1992) Expression of heparanase by platelets and circulating cells of the immune-system - possible involvement in diapedesis and extravasation. Invasion Metastasis 12:112-127

34. Romano M, Sironi M, Toniatti C, Polentarutti N, Fruscella P, Ghezzi P, Faggioni R, Luini W, Vanhinsbergh V, Sozzani S, Bussolino F, Poli V, Ciliberto G, Mantovani A (1997) Role of IL6 and its soluble receptor in induction of chemokines and leukocyte recruitment. Immunity 6:315-325

35. Sharfuddin AA, Sandoval RM, Berg DT, McDougal GE, Campos SB, Phillips CL, Jones BE, Gupta A, Grinnell BW, Molitoris BA (2009) Soluble thrombomodulin protects ischemic kidneys. J Am Soc Nephrol 20:524-534

36. Danese S, Dejana E, Fiocchi C (2007) Immune regulation by microvascular endothelial cells: directing innate and adaptive immunity, coagulation, and inflammation. J Immunol 178:6017-6022

37. Aird WC (2007) Vascular bed-specific thrombosis. J Thromb Haemost 5:283-291

38. Falati S, Gross P, Merrill-Skoloff G, Furie BC, Furie B (2002) Real-time in vivo imaging of platelets, tissue factor and fibrin during arterial thrombus formation in the mouse. Nat Med $8: 1175-1180$

39. Mackman N (2009) The many faces of tissue factor. J Thromb Haemost 7:136-139

40. Osterud B, Bajaj MS, Bajaj SP (1995) Sites of tissue factor pathway inhibitor (Tfpi) and tissue factor expression under physiological and pathological conditions. Thromb Haemost $73: 873-875$

41. White TA, Johnson T, Zarzhevsky N, Tom C, Delacroix S, Holroyd EW, Maroney SA, Singh R, Pan SC, Fay WP, van Deursen J, Mast AE, Sandhu GS, Simari RD (2010) Endothelialderived tissue factor pathway inhibitor regulates arterial thrombosis but is not required for development or hemostasis. Blood 116:1787-1794

42. Drake TA, Morrissey JH, Edgington TS (1989) Selective cellular expression of tissue factor in human-tissues - implications for disorders of hemostasis and thrombosis. Am J Pathol 134:10871097

43. Mackman N, Tilley RE, Key NS (2007) Role of the extrinsic pathway of blood coagulation in hemostasis and thrombosis. Arterioscler Thromb Vasc Biol 27:1687-1693

44. Colucci M, Balconi G, Lorenzet R, Pietra A, Locati D, Donati MB, Semeraro N (1983) Cultured human-endothelial cells generate tissue factor in response to endotoxin. J Clin Investig 71:1893-1896

45. Lupu C, Westmuckett AD, Peer G, Ivanciu L, Zhu H, Taylor FB, Lupu F (2005) Tissue factor-dependent coagulation is preferentially up-regulated within arterial branching areas in a baboon model of Escherichia coli sepsis. Am J Pathol 167:1161-1172

46. Contrino J, Hair G, Kreutzer DL, Rickles FR (1996) In situ detection of tissue factor in vascular endothelial cells: correlation with the malignant phenotype of human breast disease. Nat Med 2:209-215

47. Ryan J, Brett J, Tijburg P, Bach RR, Kisiel W, Stern D (1992) Tumor necrosis factor-induced endothelial tissue factor is associated with subendothelial matrix vesicles but is not expressed on the apical surface. Blood 80:966-974

48. Combes V, Simon AC, Grau GE, Arnoux D, Camoin L, Sabatier F, Mutin M, Sanmarco M, Sampol J, gnat-George F (1999) In vitro generation of endothelial microparticles and possible prothrombotic activity in patients with lupus anticoagulant. J Clin Investig 104:93-102

49. Tushuizen ME, Diamant M, Sturk A, Nieuwland R (2011) Cellderived microparticles in the pathogenesis of cardiovascular disease friend or foe? Arterioscler Thromb Vasc Biol 31:4-9
50. Egorina EM, Sovershaev MA, Olsen JO, Osterud B (2008) Granulocytes do not express but acquire monocyte-derived tissue factor in whole blood: evidence for a direct transfer. Blood 111:1208-1216

51. Solovey A, Kollander R, Milbauer LC, Abdulla F, Chen YIE, Kelm RJ, Hebbel RP (2010) Endothelial nitric oxide synthase and nitric oxide regulate endothelial tissue factor expression in vivo in the sickle transgenic mouse. Am J Hematol 85:41-45

52. Jasuja R, Furie B, Furie BC (2010) Endothelium-derived but not platelet-derived protein disulfide isomerase is required for thrombus formation in vivo. Blood 116:4665-4674

53. Bauer KA, Rosenberg RD (1991) Role of antithrombin-iii as a regulator of invivo coagulation. Semin Hematol 28:10-18

54. Ishii H, Salem HH, Bell CE, Laposata EA, Majerus PW (1986) Thrombomodulin, an endothelial anticoagulant protein, is absent from the human-brain. Blood 67:362-365

55. Delvaeye M, Noris M, De Vriese A, Esmon CT, Esmon NL, Ferrell G, Del-Favero J, Plaisance S, Claes B, Lambrechts D, Zoja C, Remuzzi G, Conway EM (2009) Thrombomodulin mutations in atypical hemolytic-uremic syndrome. New Engl J Med 361:345-357

56. Bajzar L, Morser J, Nesheim M (1996) TAFI, or plasma procarboxypeptidase $\mathrm{B}$, couples the coagulation and fibrinolytic cascades through the thrombin-thrombomodulin complex. J Biol Chem 271:16603-16608

57. Van de Wouwer M, Plaisance S, De Vriese A, Waelkens E, Collen D, Persson J, Daha MR, Conway EM (2006) The lectin-like domain of thrombomodulin interferes with complement activation and protects against arthritis. J Thromb Haemost 4:1813-1824

58. Fukudome K, Kurosawa S, StearnsKurosawa DJ, He XH, Rezaie AR, Esmon CT (1996) The endothelial cell protein C receptorcell surface expression and direct ligand binding by the soluble receptor. J Biol Chem 271:17491-17498

59. Bae JS, Yang LK, Rezaie AR (2007) Receptors of the protein C activation and activated protein $\mathrm{C}$ signaling pathways are colocalized in lipid rafts of endothelial cells. Proc Natl Acad Sci U S A 104:2867-2872

60. Russo A, Soh UJK, Paing MM, Arora P, Trejo J (2009) Caveolae are required for protease-selective signaling by proteaseactivated receptor-1. Proc Natl Acad Sci U S A 106:6393-6397

61. Sen P, Gopalakrishnan R, Kothari H, Keshava S, Clark CA, Esmon CT, Pendurthi UR, Rao LVM (2011) Factor VIIa bound to endothelial cell protein $\mathrm{C}$ receptor activates protease activated receptor- 1 and mediates cell signaling and barrier protection. Blood 117:3199-3208

62. Feistritzer C, Riewald M (2005) Endothelial barrier protection by activated protein $\mathrm{C}$ through PAR1-dependent sphingosine 1phosphate receptor-1 crossactivation. Blood 105:3178-3184

63. Niessen F, Furlan-Freguia C, Fernandez JA, Mosnier LO, Castellino FJ, Weiler H, Rosen H, Griffin JH, Ruf W (2009) Endogenous EPCR/aPC-PAR1 signaling prevents inflammationinduced vascular leakage and lethality. Blood 113:2859-2866 (Retracted Blood (2011) 117: 7188)

64. Niessen F, Schaffner F, Furlan-Freguia C, Pawlinski R, Bhattacharjee G, Chun J, Derian CK, ndrade-Gordon P, Rosen H, Ruf W (2008) Dendritic cell PAR1-S1P3 signalling couples coagulation and inflammation. Nature 452:654-658

65. Singleton PA, Moreno-Vinasco L, Sammani S, Wanderling SL, Moss J, Garcia JGN (2007) Attenuation of vascular permeability by methylnaltrexone - role of mOP-R and S1P3 transactivation. Am J Respir Cell and Mol Biol 37:222-231

66. Bae JS, Rezaie AR (2009) Thrombin inhibits nuclear factor kappa B and RhoA pathways in cytokine-stimulated vascular endothelial cells when EPCR is occupied by protein C. Thromb Haemost 101:513-520 
67. Van Sluis GL, Niers TMH, Esmon CT, Tigchelaar W, Richel DJ, Buller HR, Van Noorden CJF, Spek CA (2009) Endogenous activated protein $\mathrm{C}$ limits cancer cell extravasation through sphingosine-1-phosphate receptor 1-mediated vascular endothelial barrier enhancement. Blood 114:1968-1973

68. Garcia JGN, Liu F, Verin AD, Birukova A, Dechert MA, Gerthoffer WT, Bamburg JR, English D (2001) Sphingosine 1-phosphate promotes endothelial cell barrier integrity by Edg-dependent cytoskeletal rearrangement. J Clin Investig 108:689-701

69. Cao CZ, Gao YM, Li Y, Antalis TM, Castellino FJ, Zhang L (2010) The efficacy of activated protein $C$ in murine endotoxemia is dependent on integrin CD11b. J Clin Investig 120:1971-1980

70. Kerschen E, Hernandez I, Zogg M, Jia SA, Hessner MJ, Fernandez JA, Griffin JH, Huettner CS, Castellino FJ, Weiler H (2010) Activated protein $\mathrm{C}$ targets $\mathrm{CD} 8(+)$ dendritic cells to reduce the mortality of endotoxemia in mice. J Clin Investig 120:3167-3178

71. Scaldaferri F, Sans M, Vetrano S, Graziani C, De Cristofaro R, Gerlitz B, Repici A, Arena V, Malesci A, Panes J, Grinnell BW, Danese S (2007) Crucial role of the protein C pathway in governing microvascular inflammation in inflammatory bowel disease. J Clin Investig 117:1951-1960

72. Ye XB, Ding JQ, Zhou XZ, Chen GQ, Liu SF (2008) Divergent roles of endothelial NF-kappa B in multiple organ injury and bacterial clearance in mouse models of sepsis. J Exp Med 205:1303-1315

73. Song DM, Ye XB, Xu HL, Liu SF (2009) Activation of endothelial intrinsic NF-kappa B pathway impairs protein $\mathrm{C}$ anticoagulation mechanism and promotes coagulation in endotoxemic mice. Blood 114:2521-2529

74. Guitton C, Cottereau A, Gerard N, Quillard T, Chauveau A, Devalliere J, Tonnerre P, Charreau B (2011) Protective cross talk between activated protein $\mathrm{C}$ and TNF signaling in vascular endothelial cells: implication of EPCR, noncanonical NF-kappa B, and ERK1/2 MAP kinases. Am J Physiol Cell Physiol 300: C833-C842

75. O'Brien LA, Richardson MA, Mehrbod SF, Berg DT, Gerlitz B, Gupta A, Grinnell BW (2007) Activated protein c decreases tumor necrosis factor-related apoptosis-inducing ligand by an EPCR-Independent mechanism involving Egr-1/Erk-1/2 activation. Arterioscler Thromb Vasc Biol 27:2634-2641

76. Berriman JA, Li S, Hewlett LJ, Wasilewski S, Kiskin FN, Carter T, Hannah MJ, Rosenthal PB (2009) Structural organization of Weibel-Palade bodies revealed by cryo-EM of vitrified endothelial cells. Proc Natl Aca Sci U S A 106:17407-17412

77. Sadler JE (2009) von Willebrand factor assembly and secretion. J Thromb Haemost 7:24-27

78. Giblin JP, Hewlett LJ, Hannah MJ (2008) Basal secretion of von Willebrand factor from human endothelial cells. Blood 112:957964

79. Fiedler U, Scharpfenecker M, Koidl S, Hegen A, Grunow V, Schmidt JM, Kriz W, Thurston G, Augustin HG (2004) The Tie2 ligand angiopoietin-2 is stored in and rapidly released upon stimulation from endothelial cell Weibel-Palade bodies. Blood 103:4150-4156

80. Bae JS, Rezaie AR (2010) Thrombin upregulates the angiopoietin-Tie2 Axis: endothelial protein $\mathrm{C}$ receptor occupancy prevents the thrombin mobilization of angiopoietin 2 and Pselectin from Weibel-Palade bodies. J Thromb Haemost 8:11071115

81. Valentijn KM, van Driel LF, Mourik MJ, Hendriks GJ, Arends TJ, Koster AJ, Valentijn JA (2010) Multigranular exocytosis of Weibel-Palade bodies in vascular endothelial cells. Blood 116:1807-1816
82. Valentijn KM, Sadler JE, Valentijn JA, Voorberg J, Eikenboom J (2011) Functional architecture of Weibel-Palade bodies. Blood 117(19):5033-5043

83. Cleator JH, Zhu WQ, Vaughan DE, Hamm HE (2006) Differential regulation of endothelial exocytosis of P-selectin and von Willebrand factor by protease-activated receptors and cAMP. Blood 107:2736-2744

84. Turner NA, Nolasco L, Ruggeri ZM, Moake JL (2009) Endothelial cell ADAMTS-13 and VWF: production, release, and VWF string cleavage. Blood 114:5102-5111

85. Shim K, Anderson PJ, Tuley EA, Wiswall E, Sadler JE (2008) Platelet-VWF complexes are preferred substrates of ADAMTS13 under fluid shear stress. Blood 111:651-657

86. Majerus EM, Zheng XL, Tuley EA, Sadler JE (2003) Cleavage of the ADAMTS13 propeptide is not required for protease activity. J Biol Chem 278:46643-46648

87. Vomund AN, Majerus EM (2009) ADAMTS13 bound to endothelial cells exhibits enhanced cleavage of von Willebrand factor. J Biol Chem 284:30925-30932

88. Davis AK, Makar RS, Stowell CP, Kuter DJ, Dzik WH (2009) ADAMTS13 binds to CD36: a potential mechanism for platelet and endothelial localization of ADAMTS13. Transfusion 49:206-213

89. Bonnefoy A, Daenens K, Feys HB, De Vos R, Vandervoort P, Vermylen J, Lawler J, Hoylaerts MF (2006) Thrombospondin-1 controls vascular platelet recruitment and thrombus adherence in mice by protecting (sub)endothelial VWF from cleavage by ADAMTS13. Blood 107:955-964

90. Rock G, Clark W, Sternbach M, Kolajova M, McLaine P (2005) Haemolytic uraemic syndrome is an immune-mediated disease: role of anti-CD36 antibodies. Br J Haematol 131:247-252

91. Claus RA, Bockmeyer CL, Sossdorf M, Losche W (2010) The balance between von-Willebrand factor and its cleaving protease ADAMTS13: biomarker in systemic inflammation and development of organ failure? Curr Mol Med 10:236-248

92. Manea M, Karpman D (2009) Molecular basis of ADAMTS13 dysfunction in thrombotic thrombocytopenic purpura. Pediatr Nephrol 24:447-458

93. Reiter RA, Varadi K, Turecek PL, Jilma B, Knobl P (2005) Changes in ADAMTS13 (von-Willebrand-factor-cleaving protease) activity after induced release of von Willebrand factor during acute systemic inflammation. Thromb Haemost 93:554558

94. Cao WJ, Niiya M, Zheng XW, Shang DZ, Zheng XL (2008) Inflammatory cytokines inhibit ADAMTS13 synthesis in hepatic stellate cells and endothelial cells. J Thromb Haemost 6:1233-1235

95. Chauhan AK, Kisucka J, Brill A, Walsh MT, Scheiflinger F, Wagner DD (2008) ADAMTS13: a new link between thrombosis and inflammation. J Exp Med 205:2065-2074

96. Motto DG, Chauhan AK, Zhu GJ, Homeister J, Lamb CB, Desch KC, Tsai HM, Wagner DD, Ginsburg D (2005) Shigatoxin triggers thrombotic thrombocytopenic purpura in genetically susceptible ADAMTS13-deficient mice. Blood 106:723

97. Huang J, Motto DG, Bundle DR, Sadler JE (2010) Shiga toxin B subunits induce VWF secretion by human endothelial cells and thrombotic microangiopathy in ADAMTS13-deficient mice. Blood 116:3653-3659

98. Feys HB, Roodt J, Vandeputte N, Pareyn I, Lamprecht S, van Rensburg WJ, Anderson PJ, Budde U, Louw VJ, Badenhorst PN, Deckmyn H, Vanhoorelbeke K (2010) Thrombotic thrombocytopenic purpura directly linked with ADAMTS13 inhibition in the baboon (Papio ursinus). Blood 116:2005-2010

99. Sixma JJ, vanZanten GH, Huizinga EG, vanderPlas RM, Verkley M, Wu YP, Gros P, deGroot PG (1997) Platelet adhesion to collagen: an update. Thromb Haemost 78:434-438 
100. Pearson JD (1999) Endothelial cell function and thrombosis. Best Pract Res Clin Haematol 12:329-341

101. Gerritsen ME (1987) Functional-heterogeneity of vascular endothelial-cells - commentary. Biochem Pharmacol 36:27012711

102. Fulton D, Gratton JP, Mccabe TJ, Fontana J, Fujio Y, Walsh K, Franke TF, Papapetropoulos A, Sessa WC (1999) Regulation of endothelium-derived nitric oxide production by the protein kinase Akt. Nature 399:597-601

103. Dimmeler S, Fleming I, Fisslthaler B, Hermann C, Busse R, Zeiher AM (1999) Activation of nitric oxide synthase in endothelial cells by Akt-dependent phosphorylation. Nature 399:601-605

104. Ramesh S, Morrell CN, Tarango C, Thomas GD, Yuhanna IS, Girardi G, Herz J, Urbanus RT, de Groot PG, Thorpe PE, Salmon JE, Shaul PW, Mineo C (2011) Antiphospholipid antibodies promote leukocyte-endothelial cell adhesion and thrombosis in mice by antagonizing eNOS via beta $2 \mathrm{GPI}$ and apoER2. J Clin Investig 121:120-131

105. Li Z, Nardi MA, Li YS, Zhang W, Pan RM, Dang SY, Yee H, Quartermain D, Jonas S, Karpatkin S (2009) C-terminal ADAMTS-18 fragment induces oxidative platelet fragmentation, dissolves platelet aggregates, and protects against carotid artery occlusion and cerebral stroke. Blood 113:6051-6060

106. Medcalf RL (2007) Fibrinolysis, inflammation, and regulation of the plasminogen activating system. J Thromb Haemost 5:132142

107. Emeis JJ, vandenEijndenSchrauwen $\mathrm{Y}$, vandenHoogen $\mathrm{CM}$, dePriester W, Westmuckett A, Lupu F (1997) An endothelial storage granule for tissue-type plasminogen activator. J Cell Biol 139:245-256

108. Huber D, Cramer EM, Kaufmann JE, Meda P, Masse JM, Kruithof EKO, Vischer UM (2002) Tissue-type plasminogen activator (t-PA) is stored in Weibel-Palade bodies in human endothelial cells both in vitro and in vivo. Blood 99:36373645

109. Hiraoka N, Allen E, Apel IJ, Gyetko MR, Weiss SJ (1998) Matrix metalloproteinases regulate neovascularization by acting as pericellular fibrinolysins. Cell 95:365-377

110. vanHinsbergh VWM, Vandenberg EA, Fiers W, Dooijewaard G (1990) Tumor-necrosis-factor induces the production of urokinasetype plasminogen-activator by human endothelial-cells. Blood 75:1991-1998

111. Blasi F, Sidenius N (2010) The urokinase receptor: focused cell surface proteolysis, cell adhesion and signaling. FEBS Lett 584:1923-1930

112. Stratman AN, Saunders WB, Sacharidou A, Koh W, Fisher KE, Zawieja DC, Davis MJ, Davis GE (2009) Endothelial cell lumen and vascular guidance tunnel formation requires MT1-MMPdependent proteolysis in 3-dimensional collagen matrices. Blood 114:237-247

113. Prager GW, Breuss JM, Steurer S, Olcaydu D, Mihaly J, Brunner PM, Stockinger H, Binder BR (2004) Vascular endothelial growth factor receptor-2-induced initial endothelial cell migration depends on the presence of the urokinase receptor. Circ Res 94:1562-1570

114. van Hinsbergh VWM, Engelse MA, Quax PHA (2006) Pericellular proteases in angiogenesis and vasculogenesis. Arterioscler Thromb Vasc Biol 26:716-728

115. Connolly BM, Choi EY, Gardsvoll H, Bey AL, Currie BM, Chavakis T, Liu SH, Molinolo A, Ploug M, Leppla SH, Bugge TH (2010) Selective abrogation of the uPA-uPAR interaction in vivo reveals a novel role in suppression of fibrin-associated inflammation. Blood 116:1593-1603
116. Sawdey MS, Loskutoff DJ (1991) Regulation of murine type-1 plasminogen-activator inhibitor gene-expression invivo - tissuespecificity and induction by lipopolysaccharide, tumor-necrosisfactor-alpha, and transforming growth-factor-beta. J Clin Investig 88:1346-1353

117. vanHinsbergh VWM, Kooistra T, Vandenberg EA, Princen HMG, Fiers W, Emeis JJ (1988) Tumor necrosis factor increases the production of plasminogen-activator inhibitor in human-endothelial cells-invitro and in rats invivo. Blood 72:1467-1473

118. vanHinsbergh VWM, Bertina RM, Vanwijngaarden A, Vantilburg NH, Emeis JJ, Haverkate F (1985) Activated protein-C decreases plasminogen-activator inhibitor activity in endothelial cellconditioned medium. Blood 65:444-451

119. Sakata Y, Curriden S, Lawrence D, Griffin JH, Loskutoff DJ (1985) Activated protein-C stimulates the fibrinolytic-activity of cultured endothelial-cells and decreases anti-activator activity. Proc Natl Acad Sci U S A 82:1121-1125

120. van Hinsbergh VWM, Collen A, Koolwijk P (2001) Role of fibrin matrix in angiogenesis. In: Nieuwenhuizen W, Mosesson MW, DeMaat MPM (eds). Ann N Y Acad Sci 936:426-437.

121. Shaikh FM, Callanan A, Kavanagh EG, Burke PE, Grace PA, McGloughlin TM (2008) Fibrin: a natural biodegradable scaffold in vascular tissue engineering. Cells Tissues Organs 188:333-346

122. Ribes JA, Ni F, Wagner DD, Francis CW (1989) Mediation of fibrininduced release of von Willebrand-factor from cultured endothelialcells by the fibrin beta-chain. J Clin Investig 84:435-442

123. Guo YH, Hernandez I, Isermann B, Kang TB, Medved L, Sood R, Kerschen EJ, Holyst T, Mosesson MW, Weiler H (2009) Caveolin-1-dependent apoptosis induced by fibrin degradation products. Blood 113:4431-4439

124. Petzelbauer P, Zacharowski PA, Miyazaki Y, Friedl P, Wickenhauser G, Castellino FJ, Groger M, Wolff K, Zacharowski K (2005) The fibrin-derived peptide B beta(15-42) protects the myocardium against ischemia-reperfusion injury. Nat Med 11:298-304

125. Atar D, Petzelbauer P, Schwitter J, Huber K, Rensing B, Kasprzak JD, Butter C, Grip L, Hansen PR, Suselbeck T, Clemmensen PM, Marin-Galiano M, Geudelin B, Buser PT (2009) Effect of intravenous FX06 as an adjunct to primary percutaneous coronary intervention for acute ST-segment elevation myocardial infarction results of the FIRE (Efficacy of FX06 in the prevention of myocardial reperfusion injury) trial. J Am Coll Cardiol 53:720-729

126. Wijelath ES, Murray J, Rahman S, Patel Y, Ishida A, Strand K, Aziz S, Cardona C, Hammond WP, Savidge GF, Rafii S, Sobel M (2002) Novel vascular endothelial growth factor binding domains of fibronectin enhance vascular endothelial growth factor biological activity. Circ Res 91:25-31

127. Italiano JE, Richardson JL, Patel-Hett S, Battinelli E, Zaslavsky A, Short S, Ryeom S, Folkman J, Klement GL (2008) Angiogenesis is regulated by a novel mechanism: pro- and antiangiogenic proteins are organized into separate platelet alpha granules and differentially released. Blood 111:1227-1233

128. van Gils JM, Zwaginga JJ, Hordijk PL (2009) Molecular and functional interactions among monocytes, platelets, and endothelial cells and their relevance for cardiovascular diseases. J Leukoc Biol 85:195-204

129. Semple JW, Italiano JE, Freedman J (2011) Platelets and the immune continuum. Nat Rev Immunol 11:264-274

130. Lutgens E, Gorelik L, Daemen MJAP, de Muinck E, Grewal IS, Koteliansky VE, Flavell RA (1999) Requirement for CD154 in the progression of atherosclerosis. Nat Med 5:1313-1316 